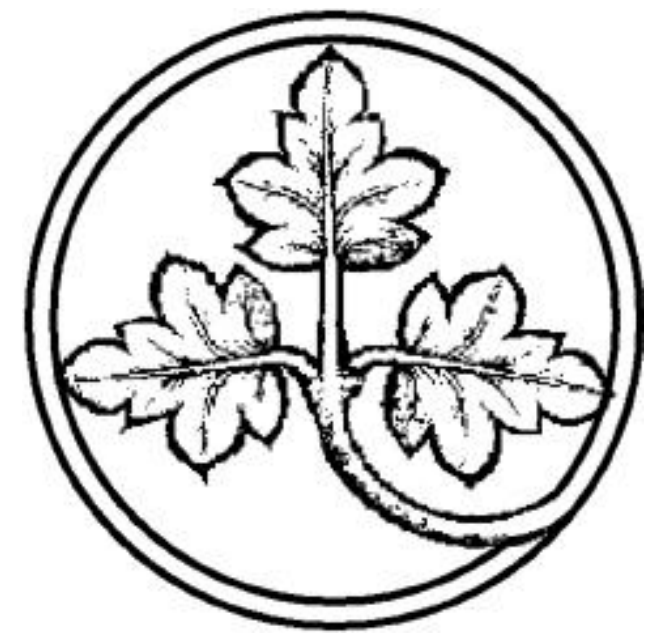

Gemeinschaftsgüter: Recht, Politik und Ökonomie

\author{
Preprints \\ aus der Max-Planck-Projektgruppe \\ Recht der Gemeinschaftsgüter \\ Bonn \\ 2000/9
}

Delineating the Proper Scope of Government A Proper Task for a Constitutional Court?

VOn

Christoph Engel 


\title{
Delineating the Proper Scope of Government - A Proper Task for a Constitutional Court?
}

\author{
Christoph Engel
}

June 2000

Max-Planck-Projektgruppe Recht der Gemeinschaftsgüter, Poppelsdorfer Alle 45, 53115 Bonn www.mpp-rdg.mpg.de 


\section{Delineating the Proper Scope of Government - A Proper Task for a Constitutional Court?*}

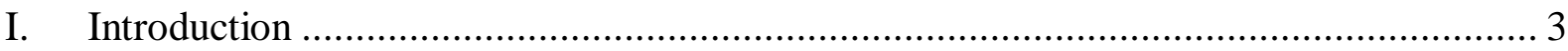

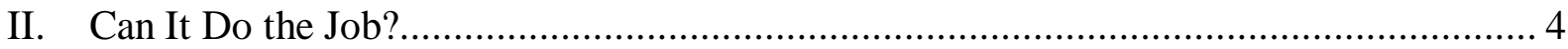

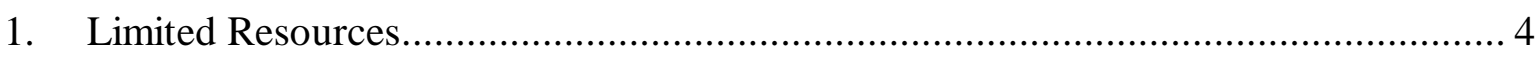

2. Remaining Autonomy of the Legislator .......................................................... 5

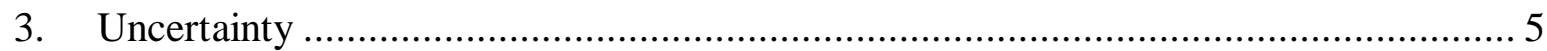

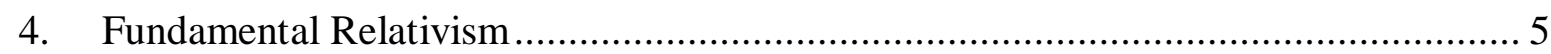

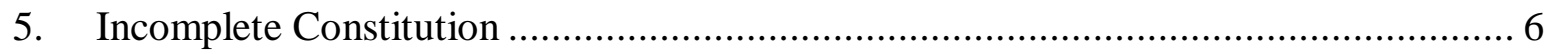

6. Properties of Legal Decision-Making .................................................................. 6

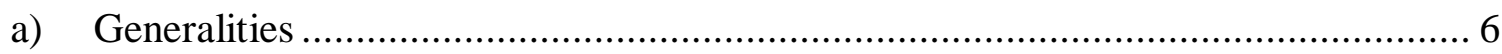

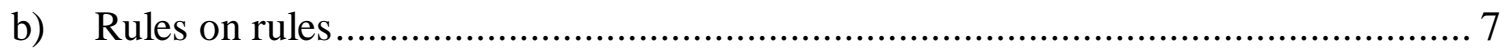

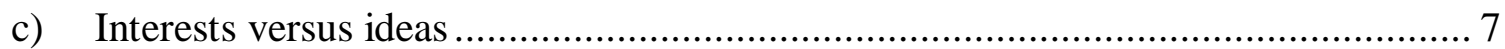

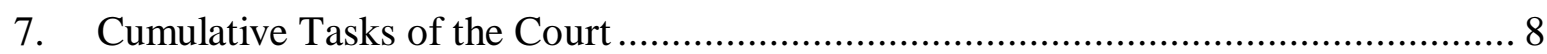

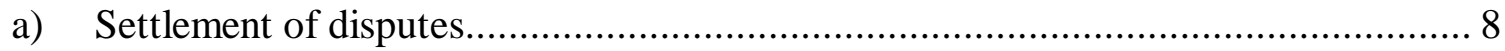

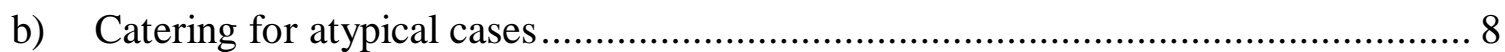

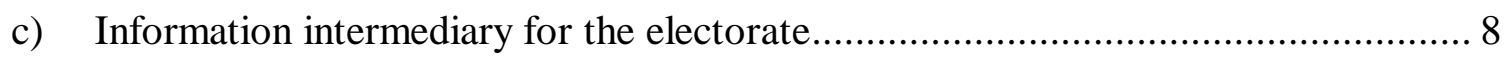

d) The court as a corporate political actor ........................................................ 9

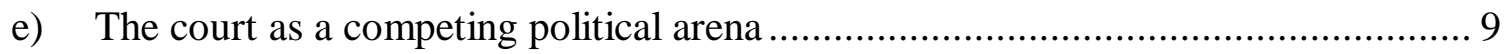

f) Voice and exit from the main political arena ................................................. 9

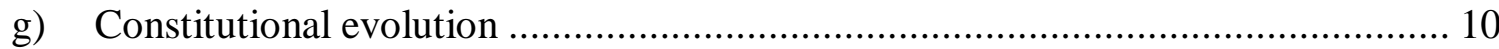

8. The Pragmatic Rationality of Open Definitions of the Common Good..................... 10

III. Will It Do the Job - Or Will It Exercise Too Little Control?....................................... 11

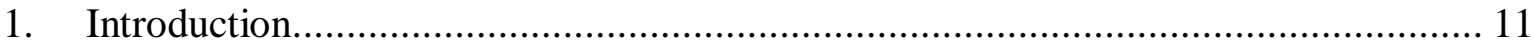

2. The Principal/Agent/Supervisor Model........................................................ 12

3. Application to the Court in a Simplified World.................................................. 13

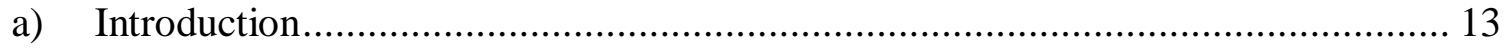

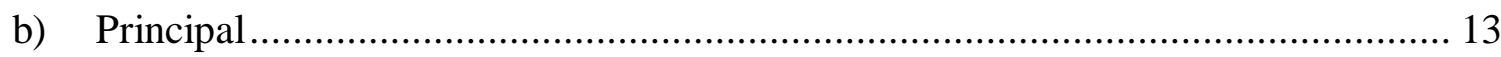

I am indebted to Markus Lehmann, Adrienne Héritier, Dieter Kerwer, Dirk Lehmkuhl and Esther Freistedt for comments and hints to material, and to the researchers of the Max-Planck Project Group for a fruitful discussion of an earlier version of this paper. 


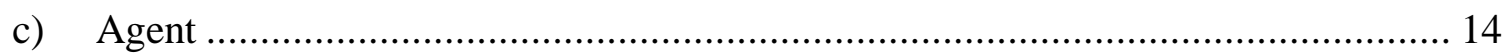

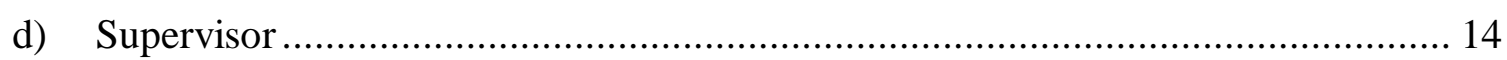

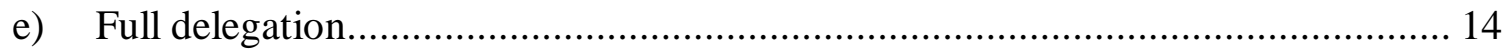

f) Interest of the legislator in a side-contract with the court ................................ 15

g) Interest of the court in a side-contract with the legislator ................................ 15

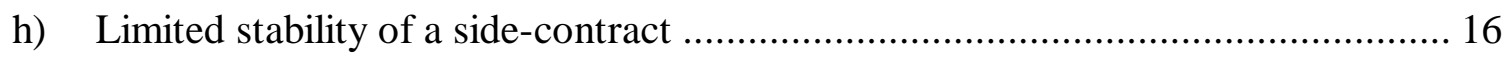

i) Making the arrangement collusion-proof on the side of the agent ...................... 17

j) Making the arrangement collusion-proof on the side of the

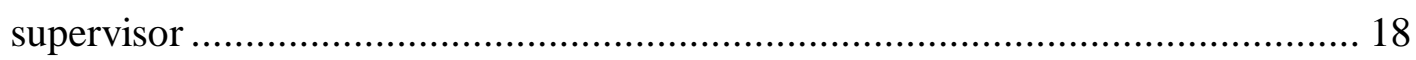

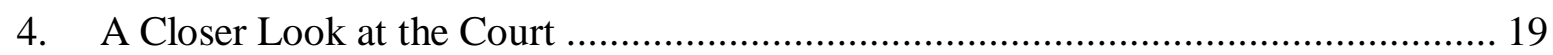

IV. Will It Do the Job - Or Will It Exercise Too Much Control? ..................................... 22

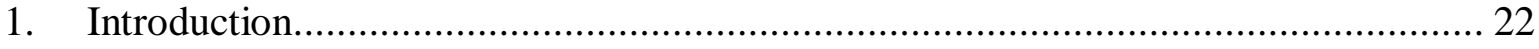

2. The Court as a Subsidiary Productive Agent .................................................. 23

3. Control of the Productive Court............................................................................. 24

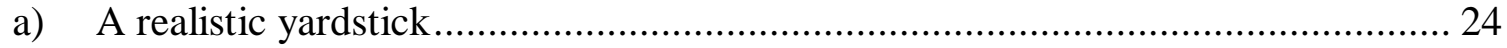

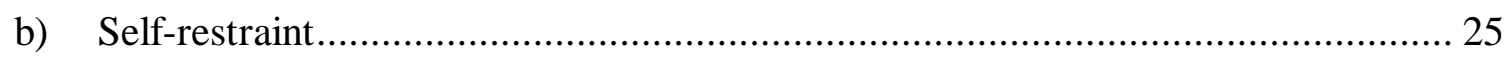

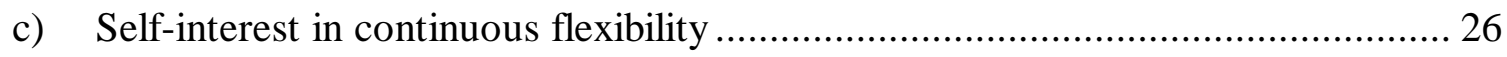

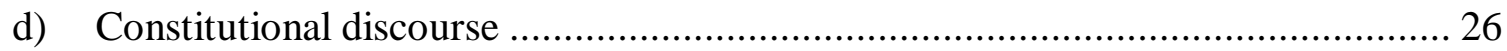

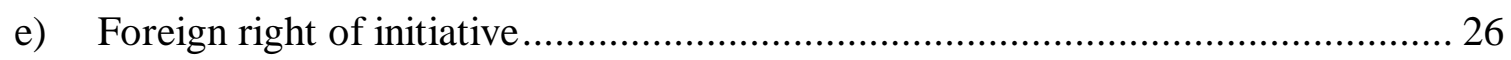

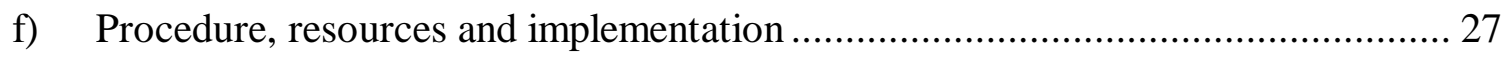

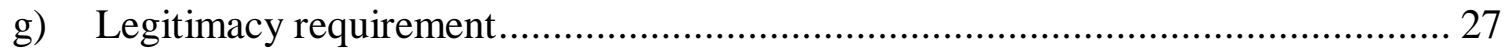

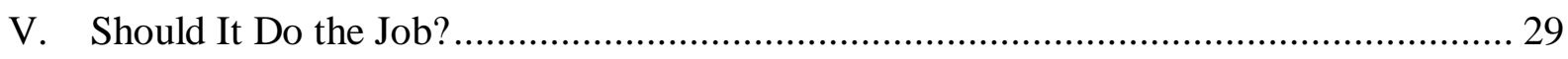

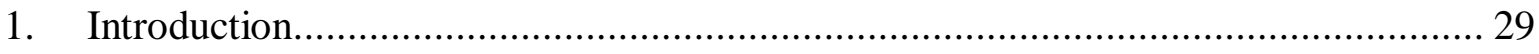

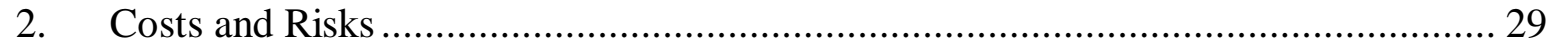

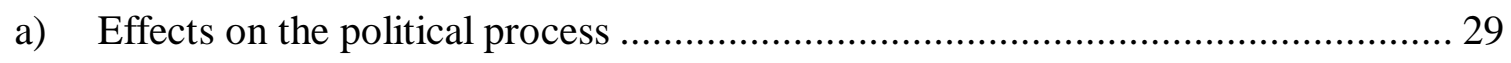

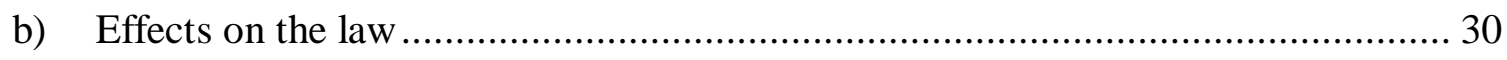

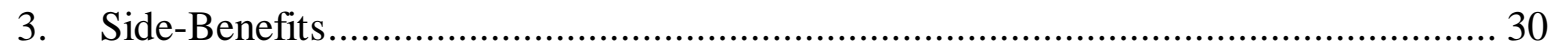

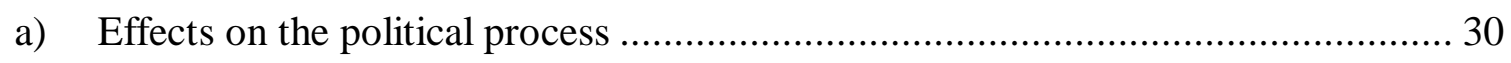

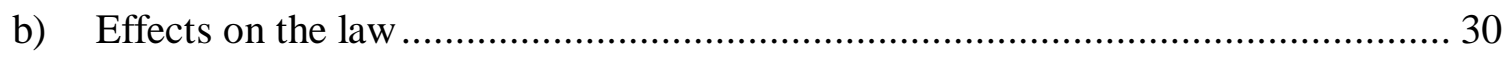

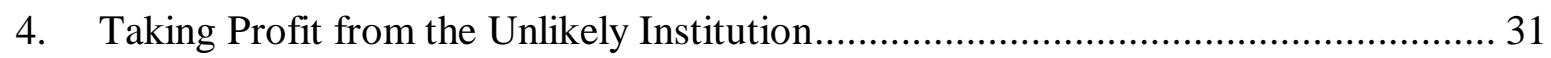




\section{Introduction}

In medieval times, every profession had its coat of arms. If the economic policy units at universities were to follow this custom, a man, a stone and a mountain would be a good choice, for the profession permanently repeats the experience of Sisyphos. Time and again it has provided excellent advice to policymakers, only to learn shortly afterwards that it has been ignored. The neighbouring unit at the economics department specialising in public choice can even give sound reasons why it could be no different. Some conclude that centralised decision making is inevitably flawed and call for minimum government. Others hope for constitutional reform. But why should those who have disproportionate opportunities within the current framework agree to its reform? Will the veil of ignorance ever be dense enough? Or does economics need civic morality as the lender of last resort (BRENNAN and BUCHANAN [1985])?

For a German lawyer, these are puzzling questions. Apparently, this country's constitution has solved the problem by setting up a constitutional court. There is virtually no government act that cannot be attacked in court, including the abstract control of statutory provisions (comprehensively SCHLAICH [1997]). The most powerful tool is the principle of proportionality (basic LERCHE [1961]). Whenever government restricts individual freedom, it must have a convincing reason. The restriction must serve this regulatory end. The legislator may not have an equally suitable, but less intrusive tool at his disposition. And the restriction may not be out of proportion. The latter requirement calls for a proper balance between the legislative end and the tool employed. Dogmatically speaking, the clout of the principle of proportionality hinges upon defining the ends the legislator may legitimately pursue. So far, the German constitutional court has not developed a consistent theory of legitimate ends, or of government tasks. This state of affairs has repeatedly been deplored in legal doctrine (comprehensively GRIMM [1994]). It is tempting to fill the doctrinal vacuum with insights from normative economic or political theory. It would then indeed become the task of the constitutional court to delineate the proper scope of government.

The solution would not work all over the world. To date, England has neither a written constitution nor a constitutional court. The Supreme Court of the United States is entitled to control legislation against constitutional precepts. But since the abolition of the Lochner jurisprudence, the US no longer disposes of a comprehensive constitutional protection against government intrusion into private freedom (for a comparison of both constitutional systems see BRUGGER [1987]). The plenitude of powers given to the German constitutional court is a highly unlikely evolution (ISENSEE [1996], 1085; SCHULZE-FIELITZ [1997], 2), to be explained in the light of German history (HÖFFE [1999]). Yet it has found successors, like the Spanish constitutional court.

This article starts from the full doctrinal potential inherent in the combination of a constitutional court with a full-fledged principle of proportionality. It further assumes that the legal concept of a legitimate end is interpreted in the light of normative theory, economic theory being part of this normative background. This will be referred to as the job entrusted to 
the constitutional court. The article asks three related questions: Can the court do this job (II)? Will it do the job (III-IV)? And should it do the job (V)? To answer these questions, it blends economic theory with insights from legal doctrine, political sciences and, occasionally, psychology.

\section{Can It Do the Job?}

The task hypothetically ascribed to the court is ambitious. Sceptics could point to an extensive list of possible impediments. The resources of the court are limited (1). For however much the court tries, the legislator will retain some autonomy (2). When it tests abstract statutory provisions against constitutional principles, the court has to decide under considerable uncertainty (3). Philosophers and cultural theorists have shown that no normative theory could entirely rest upon one fundamental norm. Constitutions implicitly acknowledge this fundamental relativism, which means that a constitutional court cannot logically deduct concrete normative results from the text of the constitution (4). Moreover, constitutions are deliberately incomplete in order to allow room for evolution and adaptation to changed circumstances (5). A constitutional court is different from an academic class in a number of respects. Academic concepts are therefore not directly translated into legal doctrine (6). Finally, testing statutory provisions against the principle of proportionality is only one of many tasks entrusted to the German constitutional court. Its control activity has to be harmonised with the other tasks of the court (7). But none of these qualifications excludes the pragmatic rationality of open definitions of the common good (8).

\section{Limited Resources}

The first limitation to control the activities of the court is straightforward, but nonetheless important. The resources that the court has at its disposition are limited. There are just two senates composed of eight judges each. Although the court aches under an ever-increasing workload, it has firmly resisted suggestions to permit its enlargement. Consistency of its jurisprudence is the main concern. Each judge has been allotted three trained clerks, that is the only alleviation. The strictly limited resources prevent judges from narrow specialisation ${ }^{1}$. Amicus curiae briefs and a one or two day hearing is the utmost the court can do to improve its expertise.

Two examples from the internal document for the division of labour among the judges of the German constitutional court illustrate the point. Judge Di FABIO is in charge of cases based on questions of public international law, law of asylum and law of foreign nationals, victims suing for prosecution, disputes among constitutional organs, and preliminary rulings on questions of customary international law. Judge HASSEMER is, inter alia, in charge of the following types of cases: disputes with municipalities, disputes with churches, and the execution of penal sentences. 


\section{Remaining Autonomy of the Legislator}

Systems theory has been most explicit at analysing the next limitation. It conceptualises the law and politics as two separate subsystems of society, governed by different codes. Whereas politics is calibrated to power, the law uses legality as its yardstick. Systems theory acknowledges that these two subsystems are closer than, say, politics and religion. They rely on each other extensively and are thus structurally linked. Yet if the law treats a statute as unconstitutional, this does not automatically make it devoid of political force. At the limit, the political subsystem could even treat the constitutional dictum as irrelevant noise. At any rate, the political system keeps some autonomy for the reaction to the invalidation of a statute by the court (SCHULTE [1996]; for the conceptional background comprehensively LUHMANN [1986]). Economists have translated these insights into their language and stress that regulatory intervention at most destroys options. The addressee is not bound to optimise under the new restrictions. The regulatory impulse can instead trigger a creative reaction (WEGNER [1996]). The same holds true for the relationship between the constitutional court and the legislature.

\section{Uncertainty}

When testing statutory provisions against constitutional principles, the court needs more than a consistent set of principles. It also needs factual information. It must know about social phenomena and, often enough, also about natural ones. The court must investigate whether the legislator has properly assessed the regulatory problem. This implies the use of pertinent models for social and natural causes and effects. Such models become even more important for the prognostic assessment implied in the question, whether a regulatory tool will meet the regulatory end (comprehensively SPIECKER [2000]). The factual basis of court decisions is particularly shaky when normative theory calls for the use of private information. For court procedure is a notoriously poor mechanism for its revelation. It is systematically poorer than even the political process. For the latter has lobbying and the resistance against the implementation of statutory rules as (weak) proxies for aggregate preferences.

\section{Fundamental Relativism}

Legalising concepts from normative theory via the principle of proportionality is plagued by a problem philosophers have long addressed under the heading of positivism. The century old search for a fundamental normative rule, from which all more concrete normative judgements could be deducted, has led to aporia. Decision making can (and should) be normatively informed. But it can not be boiled down to mathematics (Kersting [1997]). Cultural theory goes one step further. It posits different ways of life that are conceptually inconsistent with each other. It coins them the individualistic, the egalitarian, the hierarchical and the fatalistic way of life. The general normative goal is the permanent rebalancing of impulses from all four solidarities (THOMPSON, ELLIS and WILDAVSKY [1990]). Even if one were inclined to smaller doses for the intake of social constructivism, it would be hard to deny that the task of the court in assessing legislative acts is basically one associated with a balancing exercise (cf. TIROLE [1994]). 


\section{Incomplete Constitution}

The irreducible autonomy of the legislator, the inevitable uncertainty in applying normative concepts to real world problems and the fundamental relativism found in any normative judgement may all be put into one concept from institutional economics. For these three reasons, the constitution is bound to be an incomplete contract (cf. LAFFONT [1999]; for an overview of the economic theory of incomplete contracts see SCHWEIZER [1999] 239 ss.). This is obviously a counterfactual statement. No contemporary constitution relies on the actual consent of each and every national. For the German constitution, it is even worse. The Basic Law of 1994 was meant to be no more than the provisional constitution for the free part of a divided country. It therefore has not even been approved by referendum. Yet as a concept conveying legitimacy to centralised government, contract theory is a powerful tool (KERSTING [1994]). Economic contract theory fits well to that older strand of thinking. Legal doctrine is well aware of the incompleteness of the constitution. Some go as far as arguing that traditional legal methodology is of no use for constitutional interpretation (MÜLLER [1989]). One need not, however, be that radical. It is enough to stress the difference between conditionality and finality, or between rules and principles (ALEXY [1994]). Most provisions of the constitution, and fundamental freedoms in particular, are not built on a model: if A, then B. They posit normative tenets which the legislator is asked to implement to the extent possible, given competing constitutional tenets, and the circumstances of the outer world.

\section{Properties of Legal Decision-Making}

\section{a) Generalities}

The principle of proportionality has the power to translate normative theory into court practice. But it does not transform the constitutional court into an academic forum. Nor does it turn the court into an expert committee. The court is neither a scientific observer of social phenomena nor an academic advisor. It possesses jurisdiction to adjudicate. It decides. It is a social actor. This explains why normative theory is moulded by the properties of legal decision-making when applied in court. Legal doctrine and court procedure transform the original political conflict into a legal one (ISENSEE [1996], 1088). The principle of proportionality brings the court into an intermediate position between law and politics (SCHUlte [1996] 1011; SCHUlZE-FiElitZ [1997] 9).

To mention only briefly the basic properties of legal decision-making: legal governance is text-based (ISENSEE [1996] 1085). If it cannot be lege artis tied to the wording of the law, normative theory has no legal standing. Likewise it may not hamper the internal coherence of the law. Since the court takes on responsibility for the effects of its decisions in reality, it will be inclined to set aside theory if the result appears grossly unjust. The contradictory nature of court procedure will often result in competing normative constructions of one and the same real world conflict (see in greater detail ENGEL [1999]). 


\section{b) Rules on rules}

All these are properties of any legal decision making. But they are differently flavoured when the constitutional court decides upon the validity of statutory provisions. Although the procedure looks similar to a trial before the civil courts, it actually is quite profoundly different. For the constitutional court applies rules on rules. There is an underlying real world conflict. Otherwise the case would not go to court. But the settlement of this dispute is only a subsidiary task of the constitutional court. It primarily is asked to cast the dice on the validity of the underlying statutory provisions in abstracto. Many other persons will normally have trusted in the validity of the provision, and they will have rearranged life to the new norm. The court may even be misled by patent injustice in the case before it, if this is no more than an atypical incident. Applying rules on rules is thus fundamentally different from applying rules to a specific case. In the latter situation, normative theory borrowed from the social sciences may often make decisions better. But carefully looking at the facts and at the experiences condensed in legal doctrine may also do a reliable job. For rules on rules, however, the case for explicitly integrating the law and social sciences is strong.

\section{c) Interests versus ideas}

The principle of proportionality has the potential to turn court proceedings into a parallel discourse on political issues. Yet it does not simply double the discourse in the political arena. Before the court, different arguments count, and to the extent that they are admissible, the same arguments count differently. The differences are best captured by the dichotomy of interests and ideas (YEE [1996]). Court procedure basically relies on ideas, rather than on interests. Ideas matter. They shape cognition and they have an impact on the formation of preferences (GEORGE [1979]; SCHARPF [1997] 64). But ideas are not superior to interests, they are complementary. The famous dictum "judex non calculat" is telling. Ideas do not quantify, but the proper scope of government often depends on quantities. To the extent that this is the case, the court has to rely on the outcome of the political process. A second caveat is equally warranted. The political process is not devoid of ideas. But in politics the balance between ideas and interests is different. In the political process, ideas tend to be instrumentalised, and conceptual coherence is at best a subsidiary argument. Both are different in court. The foregoing also gives a better understanding of how the constitutional court and the political process are linked. The court may not only invalidate statutory provisions. By normatively reflecting interest politics, it may delegitimise political positions, stress some regulatory ideas to the detriment of others, or even coin new ones. 


\section{Cumulative Tasks of the Court}

When it decides upon statutory provisions, the constitutional court has a whole array of tasks. It has to settle the dispute among the parties who have brought the case to court (a). It has to cater for atypical cases (b). It serves as an information intermediary for the electorate (c). Its role can sometimes be interpreted as one of a corporate political actor (d). The court proceedings can in other instances be understood as a competing political arena (e). Bringing a case to court gives political actors voice or exit options (f). Deciding upon the single case is simultaneously a contribution to constitutional evolution (g).

\section{a) Settlement of disputes}

The court decides in abstracto upon the validity of the challenged statutory provisions. But it may do so only if and when there is a real dispute. The dispute may have originated among government and a citizen over the implementation of a provision. Or it may oppose political actors who have standing in court. Moot cases are not heard ${ }^{2}$. Occasionally, the settlement of this dispute and the application of normative theory clash. The intention to help the parties before it can induce the court to shape constitutional law in a way that is ultimately at variance with general theory.

\section{b) Catering for atypical cases}

Construing the principle of proportionality strictly in the light of normative theory could attach too much rigidity to constitutional provisions. It might force the court to invalidate a statutory provision, although it is quite sensible in the large majority of the cases affected by it. The law has developed a whole array of techniques for avoiding such undue rigidity. Some do not affect the incorporation of normative theory into constitutional law, like the denial of standing, or a slightly biased statement of the facts. But other techniques do, the most important being compensation instead of invalidation ${ }^{3}$. The more unusual the case appears to the judgement of the court, the more it will be inclined to protect no more than the money interests involved, not freedom ${ }^{4}$.

\section{c) Information intermediary for the electorate}

At first sight, it appears almost obvious that the court, when testing statutes against the constitution, is assessing political outcomes. From that perspective, the court would be an information intermediary for the electorate, allowing a better-informed judgement on the next election day. Sometimes, court decisions do indeed have such an effect. But it has to be qualified on both sides. Only a very small portion of the statutes promulgated by parliament go to court. And producing reliable information on the quality of parliamentary work is at best

Although the German constitutional court does not explicitly refer to this concept from US law, cf. TRIBE [1988] 83.

The German saying is "dulde und liquidiere".

The technical tool is the dogmatic figure of "enteignender Eingriff", BGHZ 111, 349, 352 s. 
a side effect of court procedure. At most it produces information about the ability and the type of politicians or political parties, not about political actions specifically (KOFMAN and LAWARRÉE [1996] 120). These qualities are no more than one element to be considered on election day, the ideological orientation being at least as important as reliability and professionalism.

\section{d) The court as a corporate political actor}

In many more instances the court behaves like an independent corporate political actor (cf. LAFFONT [1999] 665). Such a role also makes sense from a normative perspective. As we will see, the court is by no means free from external control. But the checks and balances for its jurisprudence are significantly distinct from those affecting the legislator. The court can ignore political veto points (cf. IMMERGUT [1992]). It does not have to wait for a political window of opportunity and it is not hindered by the characteristic "messiness" of politics (cf. HÉRITIER [1993]). The time horizon of the court is not limited by the next election.

In its capacity as a political actor, the court intervenes at all stages of the political process. It changes the political agenda if it deducts a duty to legislate from the constitution; if it sets a time limit for replacing an unconstitutional statute by a new one; or if it coins a new regulatory idea. The court intervenes in policy formulation if it makes itself the advocate of powerless or diffuse interests. Occasionally, it even prescribes the wording of a new statute and thereby takes the decision itself ${ }^{5}$. And via the lower courts the constitutional court has a functional equivalent to an independent implementation mechanism.

\section{e) The court as a competing political arena}

The court itself has no right of initiative. Its decisions result from a contradictory procedure before it. Both elements point to a related, but different way of conceptualising the political role of the court. In this perspective, the court would not itself be the political actor, but court procedure would be an alternative political arena. It is distinct from the ordinary political process in a couple of respects. An issue can normally only be taken to this secondary arena after a decision has been taken by the primary arena. This arena is strictly moderated by access rules and limitations on the type of argument to be heard. Moreover, the parties do not themselves decide within this arena, they only influence the outcome by their action. This way of modelling the role of the court links it to the economic discussion over systems competition (cf. GERKEN [1995]) and to the discussion on governance across multiple arenas within the political sciences (HÉRITIER, KNILL AND MINGERS [1996]).

\section{f) $\quad$ Voice and exit from the main political arena}

The court and the legislator co-exist within one and the same constitutional framework. This allows us to model the role of the court with the concepts of voice and exit (HIRSCHMAN [1970]). These notions characterise different options for members to control management, or

Most prominent are the decisions on abortion, BVerfGE 39, 1; BVerfGE 88, 203. 
of nationals to control government. Taking a case to court can be interpreted in both ways. The traditional view of judicial procedure would stress the option for those governed to complain at an independent institution about violations of their rights. If one interprets the court as a competing political arena, this is tantamount to modelling access to court as exit from the ordinary political arena. This model allows us to formulate an important insight. The exit option is elegantly moderated. Everybody can complain about any statutory provision. But in practical terms, the court is free to pick those complaints on which it decides in substance. If the complainant is dissatisfied, he has a second chance. Any lower court can refer a case to the constitutional court for a preliminary ruling on the validity of a statutory provision ${ }^{6}$. Finally, the exit option strikes back to the ordinary political arena (HÉRITIER [1999] 21). It gives those who can credibly point to a constitutional risk strengthened voice in the political process. It leads to political action in the shadow of the court.

\section{g) Constitutional evolution}

Finally, the court is also entrusted with the long-term mission of constitutional evolution. The text of the constitution is deliberately terse. This gives room for the progressive definition of the proper scope of government in the light of the experiences made. It also allows for the gradual adaptation of the constitutional framework to changed circumstances, new insights or different preferences for institutions. As is also characteristic for command-and-control regulation, the court couples this evolution mechanism with the day-to-day business of testing statutory provisions against constitutional standards (cf. ENGEL [2000]).

\section{The Pragmatic Rationality of Open Definitions of the Common Good}

It is time to come back to the initial question: Can the court do the job entrusted to it? Having read through the long list of qualifications, one might be inclined to answer this question in the negative. But there is no reason to throw out the baby with the bath water. The court will not have the opportunity to intervene whenever the ordinary political process deviates from the normative benchmark. Due to pervasive uncertainty, it will normally not dispose of all the information one might theoretically want to be available. Fundamental relativism will regularly force it into balancing exercises. The incomplete character of the constitution will sometimes leave the court without the normative yardstick one might theoretically seek to apply. Any court intervention will have to respect the properties of legal decision making. And it will have to balance delineating the proper scope of government with other tasks cumulatively entrusted to it. But none of these limitations means that the court is forced to forgo what philosophers have called pragmatic rationality (ALBERT [1979]; KERSTING [1997]). The theoretical optimum is unattainable. But by relying on normative theory, constitutions can become much better. The text of the constitutions will only very rarely determine political action. But it will more often allow negative judgements, ruling out certain means or even ends. And it will frequently put the burden of argument on one side. If this side wants to challenge traditional constitutional wisdom, it has to offer very convincing reasons, and it needs the support by thinkers of a high reputation.

$6 \quad$ Figures are to be found at http://www.bundesverfassungsgericht.de/text/statistik_1999/(29.03.2000). 


\section{Will It Do the Job - Or Will It Exercise Too Little Control?}

\section{Introduction}

Public choice theory models politicians as the agents of the public. Like any economic model it starts from the assumption that politicians maximise their utility. Since the public can at best observe the outcome, a problem of hidden action or moral hazard surges. It is compounded by the fact that the electorate is only partly informed about the competence of politicians and their willingness to act in the common interest. The electorate is thus also faced with a problem of hidden information or adverse selection (cf. SCHWEIZER [1999] 16 ss.). Economists would hardly be prepared to believe that the governance problems associated with the asymmetric distribution of information disappear once a constitutional court is added to the institutional arrangement. They would not buy the idea that constitutional judges are the last benevolent dictators of this world. They would thus also treat constitutional judges as utility maximisers.

If one starts from that assumption, adding a control agent does not become useless. The models of principal, agent and supervisor analyse the conditions under which this more elaborate institutional framework helps the principal. But these models lead the lawyer into a puzzle. For the prime concern of these models are side-contracts between the supervisor and the agent. The collusive accord induces the supervisor to keep information confidential that would be detrimental for the agent (TIROLE [1986]). The legal experience is fundamentally different from this prediction.

The lesser surprise is that collusive contracts between the constitutional court and the legislator are unheard of. Most cartels are also successively kept confidential. Or both actors might successively give their agreements a benevolent outlook.

The greater surprise concerns outcomes. The economic models predict too little control. The overwhelming majority of constitutional lawyers is concerned by the opposite outcome: too much control, or gouvernement des juges. It is true that this is only an interpretation of facts. The large majority of constitutional complaints is not accepted for decision. From those that are accepted, a majority is not successful. It is very rare that the constitutional court bluntly invalidates a constitutional provision. If it finds the provision unconstitutional, it would normally look for ways to uphold it, if only for a transition period. But it is very rare that a constitutional lawyer complains of too little court intervention into politics (one of these exemptions is SIMON [1994] § 34, R 44).

How is that puzzle to be explained? We will start with presenting the model (2). Although the relationship between the public, politicians and a constitutional court is somewhat peculiar, we will see that the gist of the model applies. The surprising outcome must therefore find an explanation within the model (3). Only after having tested the model, will we have a closer look at the court and partly revise the behavioural assumptions (4). 


\section{The Principal/Agent/Supervisor Model}

A principal/agent situation is characterised by the asymmetrical distribution of information. It basically can have three reasons: it is impossible for the principal to obtain access to the information, it is too costly to do so, or the law forbids searching for the information. In such a scenario a selfish agent can gain an information rent. He shows less effort than that for which he has contracted, or he withholds part of the gains from the principal. A rational principal anticipates such behaviour and seeks a mechanism to improve his situation.

One option is to hire yet another agent who is entrusted with a protective, not a productive role. Such an arrangement makes sense if the protective agent, or supervisor, has easier access to information about the productive agent than the principal himself. But a new principal/agent relationship surges, since the supervisor is better informed about the productive agent than the principal himself. He too can exploit the information asymmetry and gain an information rent. But since the supervisor is only a protective agent, he needs the co-operation of the productive agent. He can gain by concluding a side-contract with the productive agent. In such a contract, the supervisor promises to ignore detrimental information about the agent or to report falsely to the principal. In exchange, the productive agent hands part of his information rent over to the supervisor. Another way of putting it is this: in a principal/agent/supervisor situation, the agent and the supervisor can gain a coalition rent.

The rational reaction by the principal is to make the institutional arrangement collusion-proof. He must change the incentives in a way that makes it for either the productive agent or the supervisor irrational to conclude a collusive side contract. Basically, the principal has two options. He can credibly threaten one of the two other parties by a sanction, should a collusive side contract be detected. If the agent or the supervisor behaves rationally, he will react by multiplying the amount of the sanction with the probability of detection and enforcement. The other option is an extra reward that the principal withdraws should there be proof or even suspicion of collusion between the agent and the supervisor. A rational agent or supervisor will calculate in the same way. If all actors are fully rational, the difference between the two options thus boils down to meeting the participation constraints of the agent and the supervisor (for a more extensive treatment of the model see TIROLE [1986]; KOFMAN and LAWARRÉE [1996]; LAFFONT [1999]).

Collusive arrangements cannot normally be enforced in court. Enforcement by another third party is risky if the arrangement is illegal. For the third party might blackmail the supervisor and the agent. The enforcement problem is alleviated if the agent and the supervisor can embed the agreement into a long-term institutional framework; if not, they have to choose between risky trust and the transformation of their agreement into a self-enforcing contract (ENGEL [1999]). The latter costs them part of the collusion rent. It is therefore important for the principal to assess the risk preferences of the agent and the supervisor. 
A mechanism intended to make the arrangement collusion-proof must address either the productive agent or the supervisor. The mechanism must meet the incentive constraint of this agent. Designing such a mechanism is no easy task. For it pre-supposes that the principal correctly predicts how the productive agent and the supervisor will distribute the gains from their collusive trade. If the principal knows nothing, he is better off not having a supervisor. For the maximum collusion rent is identical with the full information rent of the productive agent. If the principal knows nothing, he must be prepared for a collusive arrangement that leaves the information rent almost entirely to the supervisor. To make the mechanism collusion-proof, the principal must invest the equivalent of the maximum collusion rent of one of the participants. Since the supervisor at the outset will also demand a wage, making the arrangement collusion-proof thus depends on at least some knowledge of the principal about the distribution of negotiating power between the productive agent and the supervisor.

\section{Application to the Court in a Simplified World}

\section{a) Introduction}

Legal readers might feel that this model has not much to do with the relationship between the legislator and the constitutional court. One must indeed make two simplifying assumptions: full rationality of all actors and the idea of a complete constitutional contract. Both assumptions are obviously counterfactual, and the court would be unable to fulfil most of its functions as delineated above (in section II), if the constitution had tried to make the constitutional contract (considerably more) complete. However, both assumptions make elements of the relationship between the three actors visible that have not been analysed by legal doctrine so far. The insights thus serve as the analytic starting point for normative conclusions in a more realistic world. The rationality assumption will be given up in section 4 , the completeness assumption in section IV.

At the outset of what follows the three actors have to be specified: the principal (b), the agent (c) and the supervisor (d). If appropriately modelled, the principal turns out to have fully delegated his power (e). The second part of the analysis looks closer at possible side contracts. Why should the agent (f) and the supervisor be interested in concluding such a contract $(\mathrm{g})$ ? How could the stability of a side contract be guaranteed (h)? This leads to the third step: how could the principal make the arrangement collusion-proof on the side of the agent (i) or the supervisor $(\mathrm{j})$ ?

\section{b) Principal}

Thus far we have somewhat vaguely referred to "the public" as the principal. Under constitutional law, this could mean two different things: the electorate or the sovereign people. The French have precise terms for the difference: the electorate is the pouvoir constitué, the sovereign people is the pouvoir constituant. The electorate is a constitutional organ, the sovereign people is the legal basis of the constitution. This is not only a doctrinal, but also a practical difference. The electorate consists of all persons who are entitled to vote. 
Minors are usually excluded, long-term foreign residents may be included and so forth. The sovereign people consists of all nationals. A second difference is even more important. The electorate is an operative organ. It becomes active on election day and for referenda. The sovereign people is only potentially active. Article 146 Basic Law as amended after reunification makes this explicit: the Basic Law becomes invalid if the sovereign people decides upon a new constitution.

As we have seen, a subsidiary task of the constitutional court is to serve as an information intermediary for the electorate. Yet its main task is different. It tests government acts against the constitution. In economic language: it enforces the constitutional contract. The appropriate way of modelling the principal is thus the sovereign people, not the electorate.

c) Agent

Lawyers will insist that under the German constitution there is no such thing as a legislator, but a legislative function entrusted to a complex interaction between several constitutional organs. Political scientists will add that legislative decisions are frequently taken by actors and in procedures not envisaged by the constitution. And they will point to the fact that politicians not only execute the public's will, but that they actually form it to a remarkable extent. All this is certainly true. But our focus is the supervisor, not the agent. From that angle, it will normally be sufficient to talk about the legislature, as if it were an uniformed political actor.

\section{d) Supervisor}

Simplifying the control agent is more critical for our topic. The constitutional court does not decide upon statutory provisions in plenary session. The competent bodies are the two senates. Each senate is composed of eight judges. Each judge has three clerks. The court has more tasks than controlling the constitutionality of such provisions. For the time being we will nonetheless refer to the court as if it were a uniform supervisor. This simplification will allow us to capture the essence of the relationship between the court and the legislature. The restrictions will be lifted in later parts of the paper.

\section{e) Full delegation}

In one characteristic respect, the relationship investigated here differs from the standard principal/agent/supervisor model. The sovereign people, i.e. the principal, is inactive. That explains why the court is not only charged with collecting information about the legislature, but also empowered to sanction the agent. The second peculiarity is related. It concerns the sanction. If a court finds out that the legislature has overstepped the constitutional limits, it neither ends the mandate of political agents nor takes resources away from them. The power to sanction is basically limited to invalidating the pertinent statutory provisions. The court thus intervenes into outcomes, not into the position of the agent. 
The constitution did do so for good reasons. The sovereign people must remain an exceptional power. Whenever asked, it legally enacts a new constitution. The constitution partly overcomes the problem by distinguishing between the sovereign people and the electorate. On election day, the electorate can disempower the previous set of agents and replace them by a new set. But the electorate is a very weak sanctioning power. It not only has to make a highly aggregate and a prognostic decision. An even more profound weakness originates in the fundamental relativism (see above II 4). Voters thus not only influence the principal/agent relationship, but they simultaneously have to decide upon the ideological orientation for the next legislative period. In giving independent sanctioning power to the court, the constitution mitigates this weakness and brings the legislator under stricter control.

Strictly speaking, the principal/agent/supervisor models do not fit such a situation. But in the literature they have already been extended to situations that are closer related. One has modelled situations, where the principal sells the structure to the supervisor (TIROLE [1986] 196). And above all: the incentive structure does not change, as the following analysis of interests will show.

\section{f) Interest of the legislator in a side-contract with the court}

Under an ordinary principal/agent/supervisor model, the agent is interested in a side-contract with the supervisor, since the supervisor can hide detrimental information or distort it. In our situation, this will at most be a subsidiary interest of the legislator, given the weakness of electoral control. But the legislator is keenly interested in suppressing the sanctioning power of the court. The court thus would have something important to offer in negotiations over the side-contract.

A qualification is warranted, but it only weakens the incentives for the legislator, without abolishing them. If it is wise, the legislator will itself be interested in some outside control. It might learn better solutions. A court dictum might be a way out of a political deadlock (SCHARPF [1999] 52 ss.). The outside evaluation provides substitute democratic legitimation (HÉRITIER [1999] 24 ss.). A rational legislator should thus be interested in a weak rather than a strong coalition with the constitutional court. Both would see at keeping up the appearence of mutual independance. But they would promise to respect the will of the other if the other credibly pretends that an issue is crucial for him.

\section{g) Interest of the court in a side-contract with the legislator}

It is less easy to determine why the court should be interested in a side-contract with the legislator. For the time being, we are treating the court as a corporate actor. We are thus only interested in incentives for the court as a whole, not for single judges or clerks. In more technical language we are thus searching for the utility function of the court.

Money will have a role to play, but one would hardly follow bureaucracy theory and model the court as a budget maximiser (cf. Downs [1957]). In the political culture of Germany it is 
unthinkable for the legislator to threaten the constitutional court with budget cuts. And whenever in the past the idea of more senates for the constitutional court came up, the court itself was the first to object. Since budget is of inferior importance, the legislator will also not offer monetary rewards, if it wants to bribe the court.

Another possibility is also not very realistic. The federal legislator and the Länder share the power to nominate future constitutional judges. In theory, the legislator might threaten the court with nominations that diminish its reputation, that make life within the court harder or that streamline the court into one political direction. But within the political culture of Germany, none of these threats is very credible. Within the electorate body, decisions have to be taken by a majority of two thirds. The political opposition sees at nominations do not render the court ineffective.

Similarly incredible is the threat to change court procedure in a detrimental way. It is true that the court does not itself formulate its procedural rules, but that they are themselves statutory provisions. But there are workable rules in force. The legislator could change or abolish them only by a new statute. This statute could itself be challenged before the constitutional court. This explains why the legislator in practise changed the court rules whenever the court asked it to do so.

The only plausible threat point for the legislator is the implementation of court decisions. The court itself has no independent power to implement or even enforce its decisions (ISENSEE [1996] 1986). It depends on the nature of a court decision, how much the court is vulnerable for that reason. If the court restricts itself to invalidating defined statutory provisions, it might hope for the lower courts disregarding them in the future. If it obliges the legislator to actively react to one of its decisions, the court must totally rely on the willingness of the legislator to abide by the judgement. The same is true for new regulative ideas by which the court tries to reshape the political agenda.

\section{h) Limited stability of a side-contract}

Collusive side agreements are illegal. Moreover, most constitutional lawyers think that constitutional organs do not have the capacity to conclude contracts over jurisdictional matters. In their judgement, jurisdiction is not a property right. It is once and forever allotted by the constitution. But even if none of these two obstacles were present, there could be no outside enforcement of the collusive agreement. For there is no court above the constitutional court. If they are rational, the court and the legislator must therefore draft the agreement in a way that also guarantees implementation. They have to face two problems. The first problem stems from the internal structure of the contracting parties. Since there is no outside enforcement, the concept of legal entities is of no help. From the point of view of the court this poses no major problem. For judges are not replaced simultaneously. The elder judges transmit the tacit knowledge of the court to their newly appointed colleagues. Had the court concluded a collusive agreement with the legislator, the majority of elder judges could train new members to apply it faithfully. 
From the point of view of the legislator, the legal starting point is more precarious. Parliament is re-elected every four years. Legally, the new Bundestag is not bound by any action from the previous Bundestag. But the total disruption is only legal, not political. If the ruling majority stays in power, the court might even meet the same leading figures, and even if the ruling majority changes, the ministerial bureaucracy gives the legislator a considerable degree of indirect stability. But full stability on the side of the legislator cannot be guaranteed.

The second problem is well-known from game theory. If the situation between two parties has been a prisoner's dilemma at the outset, a contract to overcome the dilemma leads into a second prisoner's dilemma at the implementation stage (SCHARPF [1997] 76). The parties must modify the contract in a way that it becomes a Nash equilibrium, or a self-enforcing contract (RICHTER and FURUBOTN [1999] 175 ss. ). But is the original situation between the court and the legislator a prisoner's dilemma? That would imply the following situation: each side gains most, if the other co-operates and ifself defects. If the court co-operates, this means that it upholds unconstitutional statutory provisions. If the legislator defects, this means that it disregards a court decision on another issue.

Yet the only sensible thing the legislator has to offer is its willingness to implement court decisions. This implies that the side-contract cannot be issue-specific. Only by linking issues together over time do both sides have leverage. The parties do not play a simultaneous, but a sequential game. The incentive structure is the same as that which is characteristic for a repeated game. Each party has at any given occasion the opportunity to cheat. But if it cheats, the other party has the opportunity to retaliate at the next stage of the game. Game theory shows that this is not a fully stable situation, but that stability is relatively likely (for details see BAIRD, GERTNER and PICKER [1994] 159 ss.).

Making the arrangement collusion-proof on the side of the agent

Let us sum up what we know so far: if all actors behave rationally, the legislator should be much more interested in a side-contract with the court than vice versa. But since the court has no proper implementation force, it might at least have some interest in such an agreement. Once concluded, the agreement is not fully stable. The legislator is in itself a somewhat unstable contracting party. The situation comes close to a repeated prisoner's dilemma that is not fully stable. The sovereign people therefore need not be strongly concerned about collusion between the court and the legislator. But it is not so unlikely that the people should be totally disinterested in mechanisms that cater for the remaining risk. Let us therefore finish this section by investigating how the constitution might make the arrangement collusionproof.

We remember from the original model that it suffices for the principal to change the incentives of either the agent or the supervisor. To change the incentives for the agent, i.e. the legislator, is not easy to perform. The legislator has more to gain from the collusive agreement. In all likeliness, the principal would therefore have to offer more or threaten the agent more strongly than the supervisor. In practical terms, the constitution does not have 
much more at its disposal than draconian sanctions in case the side-contract is detected. It would have to ban any politician from the political arena once he is suspected of colluding with the constitutional court. The only organ to enforce the sanction would be the electorate. This is not a particularly credible threat, given the coupling between ideological and performance judgements on election day.

\section{j) Making the arrangement collusion-proof on the side of the supervisor}

In our case, the interest of the supervisor in collusion is weaker than the interest of the agent. This makes it attractive for the principal to search for incentives to make the arrangement collusion-proof on the side of the supervisor.

Within the simplified world to which this part of our argument is confined, it is difficult to find an extra reward the sovereign people could give to the court in order to make collusion unattractive. We must therefore look out for a supplementary negative incentive. The principal, i.e. the sovereign people, is inactive. Just detection is therefore insufficient. The additional mechanism must be self-enforcing.

The German constitutional court is not the only court applying the principle of proportionality. It is also guaranteed by the European Convention on Human Rights. The parallel shows how a highly effective mechanism for the control of a constitutional court can be designed. The Convention has set up an international court to apply the European Convention on Human Rights, the European Court of Human Rights at Strasbourg. The dogmatic structure of European human rights, as construed by the Strasbourg court, is closely related to the dogmatic structure of fundamental freedoms under the German Basic Law as construed by the constitutional court (see in greater detail ENGEL [1993] 439 ss.). But the Strasbourg court has developed a doctrine of margin of appreciation accorded to the Member states. This doctrine has allowed the court to react flexibly to political resistance and different legal traditions. Moreover, it has made it possible to turn human rights' jurisprudence into a process of progressive improvement, gradually applying stricter standards (ENGEL [1986]). None of these elements is present in the jurisprudence of the German constitutional court. This difference comes as no surprise, for the European Convention on Human Rights allows Member states to give the Strasbourg court only temporary jurisdiction. All Member states have used this option and they normally give the court no more than a three years' term.

The Basic Law has given the German constitutional court permanent jurisdiction. Overt constitutional reform affecting the provisions on the constitutional court is highly unlikely in this country. Within the German constitutional order, there is only a much weaker substitute present: the already mentioned fact that the court has no jurisdiction and no means to enforce its decisions. It is therefore in its own long-term interests to see to the acceptance of its judgements (ISENSEE [1996] 1086; SCHULZE-FIELITZ [1997] 2) or to its reputation (LAFFONT [1999] 652). That this is not a tiger without teeth is shown by growing unease with judgements of the court throughout recent years (reported by HöFFE [1999]). 


\section{A Closer Look at the Court}

What we have found so far is not fully satisfactory. The risk of collusion between the court and the legislator is not negligible, the mechanisms listed so far do not reliably make the arrangement collusion-proof. We still have reason to be puzzled by the fact that lawyers only very rarely fear for too little control by the court. Let us therefore lift the restrictive assumptions by which we have started our analysis. This section takes a closer look at the court. It looks at single judges, at single clerk and at the court as composed of judges and clerks.

The fact that the court is composed of two senates having eight judges each does not only make the control problem easier for the principal. According to the procedural rules, it is precisely decisions not to control the legislator that are taken away from the senate and entrusted to chambers composed of only three judges ${ }^{7}$. The chamber only reads the complaint and the reaction by government. It neither hears the parties nor gives its reasons for its decisions ${ }^{8}$. The procedural rules thus leave ample room for laxity ont the part of the judge who reports the case to the chamber. We have reason to be even more surprised by the lack of concern among constitutional lawyers.

"The best of all monopoly profits is a quiet life" (HICKS [1935] 8). Reaping a good salary without being bothered can be the indirect information rent (LAFFONT [1999] 656). Constitutional judges are elected for a period of 12 years. Re-election is excluded. If we apply the standard assumptions of economic theory, we would thus have to predict considerable slack.

Given the procedural rules, collusive contracts with single judges would thus be attractive for the legislator. Why a judge might be interested in such a contract is less obvious, since reelection is impossible. But there might be other career goals (TIROLE [1994] 2 and 7 s.). An example is Roman Herzog who was president of the constitutional court before he became president of the Federal Republic. And the electors might be tempted to press future judges into side-contracts as a precondition for being elected. There are however three counterarguments: behavioural assumptions, selection and peer review. Let us consider them in turn.

Economic hardliners assert: "Whenever supervisors can manipulate evidence and effect payments to third parties, they will do so in their interest" (KOFMAN and LAWARRÉ [1996] 118; specifically on judges LANDES and POSNER [1975]). Other economists are more cautious (LAFFONT [1999] 651 s.; specifically on judges BOUdREAUX and PRITCHARD [1994]). This is not the occasion for extensively referring results from the sociology of judges (cf. HELDRICH and SCHMIDTCHEN [1982]; RASEHORN [1998]; LiMBACH [1999]). Some basic observations must suffice. Lawyers undergo intense professional training. The basic task of a lawyer is to interpret an abstract text in the light of the facts of a concrete case. This is not a logical operation, but a hermeneutical one. A large part of legal education is therefore dedicated to

$\S 93 \mathrm{a}-\S 93 \mathrm{~d}$ und 81a Bundesverfassungsgerichtsgesetz.

$\S 93 d$ para. 1 Bundesverfassungsgerichtsgesetz. 
train the "judicial sense", or to find a "just" solution to the underlying social conflict. In economic terms, this comes close to training preferences. Thereby preferences are not fixed, but young lawyers are taught which solutions are off the mark. Accompanying this is a strong rhetoric of responsibility. This certainly does not exclude selfish behaviour, but some intrinsic motivation may still be assumed (see also the stimulating views of VON WANGENHEIM [1995]).

Self-selection adds to the picture. The conservative bias of law students may no longer be as profound as 20-30 years ago (RAISER [1995] 396-399), but at least among lawyers selfselection seems to work. To become a judge, a young lawyer must be among the upper 15-20 percent of his class. Such lawyers can multiply their income by becoming an attorney or going into industry. If they do, working conditions are also better and the cases are more interesting. Again, there are certainly other arguments present, like better opportunities for parental leave, but it is not implausible to assume that those who become judges on average have a relatively strong sense of responsibility. It is true that not all constitutional judges were previously lower judges, but a majority of them has this background.

The constitutional court is composed of no more than 16 judges, who are elected for a period of 12 years. Being a constitutional judge is probably the most prestigious position a German lawyer can hold. Constitutional judges accordingly have much reputation to lose if narrow, selfish behaviour or collusion were detected. The election committee has such a large number of potential candidates that it is rather likely to pick persons who are not only excellent lawyers but also trustworthy.

If a single judge were detected in collusion, not only would his personal reputation be at risk, but also that of the court as a whole, and thereby the implementation of its judgements. Even if the court were mainly composed of selfish judges, strong internal peer review would thus be likely.

Finally, psychological research has uncovered the fact that visible safeguards against selfish behaviour can backfire. Such extrinsic incentives may destroy previous intrinsic motivation (FREY and BOHNET [1994]). It is true that such crowding out does not take place under all circumstances. If considered fair, the extrinsic incentive might also corroborate intrinsic motivation (DECI and RYAN [1985]). But given all the elements previously listed, constitutional judges are likely to interpret distrust in their honesty as highly unfair. They might even show what psychologists call reactance (cf. DICKENBERGER, GNIECH and GRABITZ [1993]). They might now do on purpose what previously might never have crossed their minds. All this calls for prudence when drafting mechanisms to control the remaining risk of too little control.

But judicial lenience can be framed in a way that oversteps the listed behavioural limitations. This is most likely if judges feel that lenience is the best way to serve society at large or the parties before them. Another psychological concept makes plausible why the sovereign people should not trust the judges' feelings too strongly in this respect. In the interest of 
reducing cognitive dissonance, we would rather change our preferences (or our cognitive models of the world) than live up to the difference between insurmountable restrictions and our previous preferences (FREY and GASKA [1993]). The concept of forced compliance shows that the effect is particularly strong if the restriction has only been weak to which we have subdued (ZIMBARDO [1969]). This is precisely the situation of the constitutional judges coming under pressure from political forces to which they feel ideologically close. Given the institutional framework, such forces could not break the will of a judge. But they might succeed in making her or him feel guilty.

What has been said for a single judge may grosso modo be extended to single clerks. If a constitutional court case is not obviously spectacular or politicised, the clerk may actually be the only person to really know the case. He could, accordingly, show slack or collude with the legislator. Since clerks are at the beginning of their legal careers, it might be somewhat easier for politicians to bribe them with promises of future jobs. But for the same reason, clerks are also more vulnerable. If they are reported to have openly colluded, that would mean a severe loss of reputation. The only realistic concern is thus the same as for the judges: cognitive dissonance and forced compliance in particular.

Let us finish this section by coming back to the court as a corporate actor. We mentioned earlier already that the internal structure of the court makes it a difficult partner for the conclusion of a side-agreement. We can now add that the likely behavioural assumptions for judges and clerks make it even less likely that the court engages in such behaviour. For one single judge or clerk with a strong sense of responsibility would be enough to make a collusive agreement public. 


\section{Will It Do the Job - Or Will It Exercise Too Much Control?}

\section{Introduction}

The foregoing analysis is based on one counterfactual assumption: the constitution is assumed to be a complete contract. From the first part of the analysis we know better, and we also know that this is not a flaw of the institutional design, but a necessary precondition for its adaptation to the numerous task entrusted to the court (see above II). If we now lift this assumption, we will not only find a new set of problems, but also the final answer to the concern of economists and the explanation for the opposite intuition of lawyers: too much control.

The constitutional court does not permanently intrude into politics ${ }^{9}$. But there is enough evidence for occasional judicial activism. In the case already mentioned of abortion, the court has practically written the statute ${ }^{10}$. The broadcasting jurisprudence of the court was traditionally so narrow that a liberal broadcasting policy seemed nigh on impossible (ENGEL [1994]). Many dogmatic tools developed by the court have the side-effect of extending its own power. Obvious examples are the constitutional duties to protect, derived from negative fundamental freedoms (DIETLEIN [1992]) and the so-called doctrine of essentiality (UMBACH [1994). It allows the court to invalidate a statute, because the legislator has left "essential" aspects open.

This more realistic view of the institutional framework within which the court acts does not, however, force to abandon the principal/agent/supervisor model altogether. The possibility of too little control still exists. Reform proposals have to keep that in mind. They must avoid inadvertently making this hidden danger real. More importantly: if appropriately enriched, the principal/agent model is able to conceptualize the role of a court in a world with an incomplete constitutional contract as well. Two amendments are warranted. In such a world, the court is not only the supervisor of the legislator, but subsidiarily itself a productive agent (2). This also changes the conditions for the control of the court (3).

In order not to be misunderstood: this is not to say that principal-agent models were the only conceptual tool for understanding the proactive constitutional court. A particularly attractive competitor are evolutionary models, stressing the role of the court in generating variation where the political process has led into a deadlock, and in selecting some of the outcomes of the political process to the detriment of others. Put differently: in applying the principal-agent model, all the possible court functions delineated above are put together into the notion of the incomplete constitutional contract. This makes it impossible to answer the related question, how much latitude the court should have. But as we will see, this simplification is justified since we are here interested in the ensuing control problem. The simplification is in the interest of keeping the model as parsimonious as possible.

\footnotetext{
9 The ensuing question under what conditions the court may be expected to become politically active is beyond the scope of this paper. 


\section{The Court as a Subsidiary Productive Agent}

In a world with an incomplete constitution, the role of a constitutional court is inevitably altered. We remember that the principal, for sound reasons, is inactive and has charged the court with the double task of analysing the behaviour of the legislator and sanctioning it if it oversteps constitutional limits (see above III 3 e). In so doing, the court is forced to fill constitutional gaps, which is tantamount to forming an independent political will. And by sanctioning the legislator, this political will is translated into political action. Thereby the court (at least subsidiarily) becomes a productive agent. The court can be interpreted as the governance structure for the incomplete constitutional contract.

This view becomes even more convincing if we relate the interpretation back to what we originally found out about the relationship between the social sciences and the work of a constitutional court. The subsidiary productive task of the court also roots in the pervasive uncertainty about the facts (see above II 3) and in the fundamental relativism (see above II 4). The court is meant to balance the focus of the political process on interests by a focus of the constitutional discourse on interests (see above III $6 \mathrm{c}$ ). Finally, the court sees at the evolution of the constitution to changed circumstances or attitudes (see above II $7 \mathrm{~g}$ ). Lawyers rightly sum it up: constitutional jurisprudence is politics by different means (ISENSEE [1996] 1085; see also SIMON [1994] § 34, R 42 and R 46; and - with a sceptical attitude, BÖCKENFÖRDE [1999] 67).

There are basically two strategies for adapting the model to this more realistic view of the court. The more radical strategy would do away with principal/agent/supervisor model and conceive of the court as yet another productive agent (cf. for such models TIROLE [1986] 183; LAFFONT [1999] 657-660). This would be in line with the idea that the court is an autonomous political actor (see above II $7 \mathrm{~d}$ ). But, in essence, the court is still the supervisor of the legislator. It only subsidiarily develops its own political will and reshapes politics. This makes it more appropriate to adhere to the principal/agent/supervisor model, but to enlarge it.

If one does so, the utility function of the court becomes more complex. The court is now also interested in preserving, perhaps even extending the space for subsidiary political action. This may be a means of bringing political outcomes closer to the will of the principal, but it need not be so. For the court can also use the autonomy for correcting outcomes of the political process that are well in line with the will of the people, but not with the personal interests or ideas of the judges.

It now also becomes understandable why too much control is not even mentioned in the economic literature on principle/agent/supervisor models. These models, sometimes implicitly, assume that the agent and the supervisor are profit maximisers. Under that assumption, it makes no sense for the supervisor to partly take over. The agent and the supervisor get all their income from the principal or a supervisor can improve his income only via a side-contract with the agent. If, however, the supervisor is also interested in partly becoming the agent itself, the incentive structure changes. 
At first sight, this makes the situation of the principal even more precarious. For it might seem as if the legislator now had even more leverage for negotiations with the court over a sidecontract. It would no longer be limited to threatening the court (see above III $3 \mathrm{~g}$ ). For the legislator might offer the court a small portion of political power in return for less control, one might think. At closer sight, however, the situation is different. For under the German constitution, the jurisdiction to prescribe is not a property right of the legislator. Legally speaking, the legislator is unable to transfer it partly to the court. The same is also true politically. The court cannot simply utter a political will. It can only indirectly influence political outcomes in the ways described above: via invalidating statutory provisions, closing narrow political windows of opportunity or coining new regulative ideas.

This insight allows us to fully integrate the subsidiary, productive role of the court into the principal/agent/supervisor model. It turns out to be precisely the reward given by the principal to the supervisor for making the institutional arrangement collusion-proof. Occasionally imposing its political will on the indirect ways just described is much more attractive for the court than concluding a side-contract with the legislator.

\section{Control of the Productive Court}

a) A realistic yardstick

From the principal's perspective, the court, in its subsidiary, productive role is an agent. The principal would have a difficult time in closely observing the action of this productive agent. But the principal does not even try. The sovereign people as an actor is inactive. It controls and sanctions the constitutional court no more than it does with the legislator. For two reasons, the principal/agent problem is even more acute. The sovereign people canot even rely on the electorate, for the electorate has no say on the court, not even every four years. The productive activities of the court are not controlled by any other separate supervisor either.

Thus far, the institutional arrangement looks strongly flawed. But our judgement should not be misled by an unrealistic yardstick. First and foremost, we have to keep in mind that the two parts of our analysis are linked. Some leeway for the productive court is the price to make the principal/agent/supervisor arrangement collusion-proof. The principal gets reliable constitutional control of the political process in return. Given the incentive structure inherent in the political process, abuse of legislative power is much more likely than abuse of judicial power. One can only ask whether the price paid by the principal is too high.

One should further keep in mind that the subsidiary productive activity of the court is in itself not a price paid by the principal but, on the contrary, a service to the principal. As we have repeatedly mentioned, the court has more tasks to fulfil than controlling the legislator, like evolving the constitution (see above II). There are only two constellations in which the principal actually pays a price: the court becomes productive although the situation would only call for a protective role; the court rightly becomes productive, but it imposes a political will not corroborated by the principal. 
A last caveat should be kept in mind. Game theoretic analysis shows that too much safety does not pay. For absolute safety leads to a solution concept that game theorists call maximin. If one player adopts that strategy, all potential gains from trade are eaten up. Co-operation becomes useless (SCHARPF [1997] 40). The principal should thus be content with arrangements that make it reasonably unlikely for the court to abuse its subsidiary productive powers. This section purports to evaluate the mechanisms that are already at work in German constitutional life.

Constitutional lawyers put most stress on self-restraint (b). This is a highly valuable tool. But its potential can only be assessed in the light of a simultaneous array of extrinsic mechanisms. They rely on the self-interest of the court in continuous flexibility (c) and on the constitutional discourse (d). Additional safeguards originate in the foreign right of initiative (e), the internal rules of procedure, the limited resources of the court and, above all, the missing implementation power (f). It makes continuous reputation, or legitimacy, a paramount concern for the court $(\mathrm{g})$.

\section{b) Self-restraint}

Among constitutional lawyers, our problem is normally discussed as one of self-restraint (RAU [1996]); see also HÖFFE [1999] 180-183, but SIMON [1994] § 34, R 47 s.). The court has indeed been as inventive for limiting the intensity of control as it has been for extending it (see above 1). It points to the fact that the constitution is no more than a framework within which the legislator remains free to act (BÖCKENFÖRDE [1976] 2091, 2099). It is unwilling to force the legislator to be consistent. As long as the legislator does not overstep the constitutional limits, one statute can point into one direction, the next statute into the opposite direction $^{11}$. Equally weak is the control for egality ${ }^{12}$. The legislator has considerable leeway when it comes to prognostic assessment ${ }^{13}$ and it may make legislative experiments ${ }^{14}$.

From the functional perspective of this paper, self-restraint may be interpreted as intrinsic motivation. Intrinsic motivation does not surge at random, and it is plastic to changes in the institutional framework. This is why it fits here. But intrinsic motivation does not originate in strategic action. It basically is culturally determined. This is why the degree of judicial activism or judicial restraint can not be explained entirely by the institutional opportunity structure within which the constitutional court acts.

Since it applies to the court in its entirety, the intrinsic motivation is corroborated by peer review among the judges and clerks. We have shown why the principal has reason to be optimistic in this respect (see above III 4). As long as crowding-out is avoided, however, it is useful to buttress the attitude of judges and clerks by incentives and an appropriate institutional framework.

BVerfGE 59, 36, 49; 61, 138, 148; 68, 237, 253.

BVerfGE 9, 201, 206; 99, 280, 290; 100, 195, 205.

BVerfGE 50, 290, 332; 99, 367, 389; 99, 341, 354.

BVerfGE 43, 291, 321; 49, 89, 130; 56, 54, 80; 83, 1, 21 s.; 95, 267, 310. 
A first incentive argument relies on the time horizon under which the court acts. Although the court is not legally prevented from overruling its earlier jurisprudence, it is very rare that the court does so in the open. Gradually giving an older tenet a new meaning happens more frequently. But it is still unusual, and the very interest to make the change less visible is also a considerable limitation. Unlike the legislator, the politically active court is bound by a consistency requirement. One can give a legal and a political reason for this. Legally, the constitution is interpreted as a coherent body of norms to be gradually specified into doctrinal concepts. Politically, consistency is paramount, since the court basically relies on ideas, not on interests (see above II 6 c). Interest-based governance can forego consistency without delegitimising itself. Preferences may have changed. Compromises between divergent interests regularly lead into package deals that openly defy consistency. All this is different for ideasbased governance. Judicial self-restraint is thus not only motivated by respect for the legislator or by the constitutional limitations for judicial activism. It can equally be the result of long-term preferences of the court and its judges.

\section{d) Constitutional discourse}

The next safeguard is closely related to the foregoing. Although there is no proper legal supervisor, the productive activities of the court have high visibility. The more politicised an issue, the more intensely a court decision will be discussed in the media and among the public at large. When the court forbade crucifixes in the classroom, public uproar was triggered (more by SCHULZE-FIELITZ [1997] 2 ss.). While this is a rare incidence, nearly every court decision is intensely discussed among lawyers. For the very reasons just stated, the constitutional discourse is not only a legal, but also a political restriction. For it points to inconsistencies, and it shows how different ideas would also lead to different court interventions into politics.

\section{e) Foreign right of initiative}

The court is not only a subsidiary, it is also a weak political actor. For it cannot become active if it feels that things go wrong and should be back on constitutional track. The court has no independent right of initiative. It must wait until a case is brought before it. This restriction should, however, not be overstated. The court receives more than 4,000 constitutional complaints a year. From these complaints, it can pick those issues it deems fit. By one proactive decision, the court can trigger further complaints and it can thus relatively quickly give a whole field of law a new outlook or propagate a new regulative idea. A good case in point is the court decision on census. In that decision, the court derived a right to informational self-determination from the constitutionally guaranteed human dignity ${ }^{15}$. This turned Germany into the forerunner of data protection (BURKERT [2000]).

15 BVerfGE $65,1$. 
The next set of restrictions has already been analysed in greater detail above (see above III $3 \mathrm{~g}$ and III 4). It is, however, worth underlining that these restrictions have a more profound impact on the productive than on the protective court. As mentioned, a single judge, even a single clerk, would not so rarely have an opportunity to collude with the legislator (see above III 4). This is not true for the productive court. In order to invalidate statutory provisions, the whole senate is needed. A judge with a distinct political will must at least win over the majority of his colleagues. Not legally, but practically, the same is true for other techniques through which the court becomes politically active. In legal theory, a chamber comprising three judges might use the underlying reasons behind a decision as a platform for influencing politics. But most of the chamber decisions are not even published. If they are, everybody knows that this is not the conviction of the whole senate. And, above all, it would be difficult within the court to make extensive use of that option. The peer judges do not only dispose of moral suasion. At the limit, they might even change the fields charged to a judge or the composition of a chamber.

A further restriction roots in the fact that the court is composed of no more than 16 judges forming two senates. Again, the limitative impact on the productive court is greater than on the protective court. The reason is the same as has just been mentioned: in practical terms, only the senate as a whole can become politically active. And the more profound the impact of a court decision on politics, the more careful and usually also the more extensive the reasons must be spelt out. Each senate can only take a very limited number of such decisions in a year.

The most important limitation, as for the protective court, stems however from the missing power of implementation. It again has a much greater bearing on the productive court than it has on the protective court. If the protective court invalidates a statute, it can hope for the lower court's disregarding the provision. In principle, the lower courts will also take up new regulatory ideas coined by the court. But such ideas at best become an element in the reasoning of the lower courts. There is thus no automatic implementation, as with invalidation. That gives the lower courts considerable leeway. And the lower courts have no possibility of intervention if the constitutional court exclusively addresses the legislator, as with a constitutional duty to protect.

\section{g) Legitimacy requirement}

In itself, legitimacy is not a functional concept. The governance perspective and the legitimacy perspective are distinct. Yet the foregoing already reveal arguments why legitimacy has a functional side effect. The higher the court ranks in public esteem, the more the implementation of its decisions goes without saying. The constitutional discourse then deepens the conceptual basis of court jurisprudence, rather than destabilising it as an institution. The public then expects help from court and uses its right of initiative to open new opportunities for the court. If we look at the opposite scenario of eroded legitimacy, the need 
for public and professional support becomes even more obvious. The legislator might start playing cats and dogs with the court and find ways to make the life of the court harder (cf. above III $3 \mathrm{~g}$ ). In the long run, a change in the pertinent provisions of the constitution might even cut back the jurisdiction of the court.

There are in principle two ways for political action to gain legitimacy: input- and output legitimacy. The first mechanism relies on delegation. The political action is legitimate because it roots in a decision of those governed, be that election or referendum. Output legitimacy relies on the quality of political outcomes. If the large majority of those governed is convinced that a certain policy leads to social betterment, this gives the policy legitimacy (SCHARPF [1999] 16-28). The constitutional court can in principle rely on a mixture of inputand output legitimacy. But both elements are weak. This weakness forces the court to be permanently sensitive to erosion.

At first sight, it may appear surprising that the court disposes of any input legitimacy. For the court is deliberately independent of the ruling majority, and therefore of the electorate (SCHARPF [1997] $153 \mathrm{~s}$.). The only indirect link to the electorate is the election committee for the judges. As mentioned, half of the electors are members of parliament, the other half are delegated by the Länder. But the court is not just another independent organ, similar to the central bank or the European Commission. The entire power of the court is text-based. How politically active it becomes, it always does so by interpreting the constitution. In principle, the court thus disposes of input legitimacy directly from the sovereign people. But the constitution has only a few rules and mainly principles (see above II 5). As pointed out earlier, principles only determine a regulatory goal, not the regulatory means. The court therefore disposes of only weak input legitimacy.

There is basically one reason why the legitimacy of other independent organs is usually not questioned: they are single-purpose institutions with a precisely defined task ${ }^{16}$. The federal cartel authority seizes at workable competition, the federal court of auditors seizes at parsimony of government spending. The constitutional court is not in an equally comfortable position. Given the fundamental relativism, it regularly has to engage in balancing opposing views of the world (see above II 4). That makes it much more difficult to produce evidence for effective problem-solving (cf. SCHARPF [1999] 20). Accordingly, also output-legitimacy is weak.

16 I owe this thought to Wernhard Möschel. 


\section{Should It Do the Job?}

1. Introduction

We have visited a complex institution. It is not perfect. Collusion between the court and the legislator is highly unlikely. But the safeguards against abusive political action by the court are not watertight. The normative recommendation can thus not be straightforward. If there were more space than we have in this article, we would have to engage in institutional comparisons. We might start by slightly altering the institutional structure. The right of initiative might be entirely taken away from the constitutional court, or another institution might decide about the cases heard by the constitutional court. Some of the dogmatic tools might be abolished that allow the court to become more or less active, as it deems fit. More radical solutions might bring the principal back in, for instance by referendum. Even if legally admissible, the court control of referenda would be hard to defend politically. Or one might consider trading some constitutional control of the political process for fewer opportunities for court activism. The U.S. constitution, with its limited set of fundamental freedoms, is a case in point. But all such institutions would themselves have to be analysed within the institutional framework of the German polity.

This section is deliberately more modest. It comes back to the original question. Should it be the task of the German constitutional court to delineate the proper scope of government ? Should the court thus be encouraged to transpose insights from the social sciences to constitutional law ? This section points to concomitant costs and risks on one hand (2) and to side-benefits on the other hand (3) and concludes with a recommendation (4).

\section{Costs and Risks}

The last sections have exclusively looked at one class of costs and risks implied in the institution of a constitutional court: too little or too much control. But the institution also has effects on the political process (a), and it changes the conditions for governance through law (b).

\section{a) Effects on the political process}

The option of taking a political issue to court changes the political process. Those who can credibly threaten to take an issue to court gain leverage in negotiations with opposing political actors. The threat of court intervention can partly disempower politics (cf. ISENSEE [1996] 1085). It can have a chilling effect on policy makers, destabilise government and delegitimise politics. Since political actors face court intervention, they lose flexibility (cf. LAFFONT [1999] 652; BÖCKENFÖRDE [1990] 69). Finding a political compromise becomes more difficult, since the underlying conflict of ideas can still be taken to court. 


\section{b) Effects on the law}

The effect on the law can best be explained in the terminology of systems theory. Since the court subsidiarily fulfils a political function, the difference between the subsystems politics and law is somewhat blurred. Both subsystems gain more resonance for the neighbouring subsystem but pay for it with a reduced capacity to handle complexity (LUHMANN [1986] 40 ss.). Jurisprudence risks becoming politicised (ISENSEE [1996] 1085) and thereby losing some of its normative clout (BÖCKENFÖRDE [1976] 2097).

\section{3. $\quad$ Side-Benefits}

Risks and opportunities are twins. It therefore comes as no surprise that the listed risks are mirrored in side-benefits for both the political process a) and the law b).

\section{a) Effects on the political process}

The subsidiary political activity of the court caters for characteristic deficiencies of the political process. It is characteristic for this process that options are progressively narrowed (SCHARPF [1997] 80 s.). This can go as far as sticking to an agenda although the problem no longer exists that originally attracted public attention. Another characteristic are narrow political windows of opportunity or even stalemates resulting from insurmountable veto points (see above II $7 \mathrm{~d}$-f). The court can find innovative shortcuts for such political deadlocks (HÉRITIER [1999] 35). At times it may be helpful to have a forum for politics below the threshold of public attention (SCHARPF [1999] 31). Voices that were not heard in the ordinary political process can use the court for re-balancing the decision-making process (ISENSEE [1996] 1088).

As mentioned, there is a characteristic divide among the legislator and the court over the impact of interests versus ideas. For the legislator, interests count first, for the constitutional court, ideas. Since political actors know that the issue can later on go to court, they have a greater incentive to look at ideas from the outset.

Finally, the right of each individual to take a statute to court gives the political process extra legitimacy (DWORKIN [1991]; HÉRITIER [1999] 24, 26 s., 37). Such legitimacy is particularly valuable if the underlying conflict has a redistributive character and log-rolling or compensation prove infeasible (SCHARPF [1997] 154 s.).

\section{b) Effects on the law}

Again, systems theory is the best analytical tool for characterising the positive effects of subsidiary political action by the constitutional court. Since the court is aware that potentially each decision may turn from a purely legal into a partly political one, its sense for the underlying political conflict is sharpened. Systems theory would call that: the subsystem law becomes more resonant for signals sent out by neighbouring subsystems (LUHMANN [1986] 
40 ss.). That prevents constitutional law from becoming too self-referential, therefore too disturbing for the political process.

\section{Taking Profit from the Unlikely Institution}

At the end of our analysis, we cannot come up with a mathematical exercise. The recommendation cannot logically be deducted from a set of observations and a list of causal relations that are out of dispute. We are still faced with the necessity of deciding, and of taking on responsibility for constitutional design.

Furthermore, this decision cannot be one of 'yes' or 'no'. As in pharmacy, dosis facit venum. We are neither pleading for Plato's kingdom of philosophers, nor for a political process uncontrolled by an external supervisor and a subsidiary productive agent.

This leads to a third caveat. In the language of Karl Popper: "Institutions are like fortifications. They have to be wisely designed, but also properly manned." (POPPER [1957] 53). The constitutional goal can thus not be a court prepared for monsters in robe. The constitution may look at the likely behavioural patterns and selection mechanisms. But this also means that the current institutional structure need not be the right one forever. And it means that the public and the profession are rightly concerned about who is elected a constitutional judge.

Finally, the recommendation should not be made for a world free of social and historical context. It may well be that the current institutional structure is a legacy of the German postwar period with its almost naïve belief in the power of law. But the German people has any reason to take profit from the historically unlikely institution of a powerful constitutional court. Despite some tremblings a couple of years ago, this institution is still profoundly trusted by the people, the profession and even politicians. If it does not go to excess, the court could and should well use this position for improving political outcomes by giving regulative ideas clout in the political process. Normative social sciences are the best place for finding and testing sound regulative ideas. 


\section{References}

AlBeRT, H. [1978], Traktat über rationale Praxis, Mohr: Tübingen.

ALEXY, R. [1994], Theorie der Grundrechte, Suhrkamp: Frankfurt ( $2^{\text {nd }}$ edition).

Baird, D.G., Gertner, R.H. and PICKER, R.C. [1994], Game Theory and the Law, Harvard University Press: Cambridge, Mass.

BÖCKENFÖRDE, E.-W. [1976], „Die Methoden der Verfassungsinterpretation: Bestandsaufnahme und Kritik“, Neue Juristische Wochenschrift 46, 2089-2099.

BÖCKENFÖRDE, E.-W. [1990], Zur Lage der Grundrechtsdogmatik nach 40 Jahren Grundgesetz, Carl-Friedrich-von-Siemens-Stiftung: München.

BoudreauX, D.J. and PRITCHARD, A.C. [1994], „Reassessing the role of the independant judiciary in enforcing interest-group bargains“, Constitutional Political Economy 5, 1-21.

Brennan, G. and Buchanan, J.M. [1985], The Reason of Rules: Constitutional Political Economy, Cambridge University Press: Cambridge.

BRUGGER, W. [1987], Grundrechte und Verfassungsgerichtsbarkeit in den Vereinigten Staaten von Amerika, Mohr: Tübingen.

Burkert, H. [2000], „Privacy - Data Protection: A German/European Perspective“, pp. 4369 in: ENGEL, C. and KELLER, K.H. (ED.), Governance of Global Networks in the Light of Differing Local Values, Nomos: Baden-Baden.

DECI, E.L. and RyAN, R.M. [1985], Intrinsic Motivation and Self-Determination in Human Behavior, Plenum Press: New York.

Dickenberger, D., GNIECH, G. and GrabitZ, H.-J. [1993], „Die Theorie der psychologischen Reaktanz“, pp. 243-274, in: FREY, D. and IRLE, M. (ED.), Theorien der Sozialpsychologie I: Kognitive Theorien, Huber: Bern ( $2^{\text {nd }}$ edition).

DietLein, J. [1992], Die Lehre von den grundrechtlichen Schutzpflichten, Duncker \& Humblot: Berlin.

Downs, A. [1957], An Economic Theory of Democracy, Harper: New York.

Dworkin, R. [1991], Taking Rights Seriously, Duckworth: London (6 ${ }^{\text {th }}$ edition).

ENGEL, C. [1986], „Die Schranken der Schranken in der Europäischen Menschenrechtskonvention. Das Merkmal ,notwendig in einer demokratischen Gesellschaft' in den Schrankenvorbehalten, das Diskriminierungsverbot, und die ,margin of appreciation', Österreichische Zeitschrift für Öffentliches Recht und Völkerrecht , 37, 261-287.

ENGEL, C. [1993], Privater Rundfunk vor der Europäischen Menschenrechtskonvention, Nomos: Baden-Baden. 
ENGEL, C. [1994], „Rundfunk in Freiheit“, Archiv für Presserecht, 25, 185-191.

ENGEL, C. [1999], „Vertrauen: ein Versuch“, Gemeinschaftsgüter: Recht, Politik und Ökonomie. Preprints aus der Max-Planck-Projektgruppe Recht der Gemeinschaftsgüter Bonn, 1999/12.

ENGEL, C. [2000], „Die Grammatik des Rechts: Funktionen der rechtlichen Instrumente des Umweltschutzes im Verbund mit ökonomischen und politischen Instrumenten“, Gemeinschaftsgüter: Recht, Politik und Ökonomie. Preprints aus der Max-PlanckProjektgruppe Recht der Gemeinschaftsgüter Bonn, 2000/3.

FREY, B.S. and BOHNET, I. [1994], „Die Ökonomie zwischen extrinsischer und intrinsischer Motivation“, Homo Oeconomicus, 11, 1-20.

FreY, D. and GASKA, A. [1993], „Die Theorie der kognitiven Dissonanz“, pp. 275-324, in: FREY, D. and IRLE, M. (ED.), Theorien der Sozialpsychologie I: Kognitive Theorien, Huber: Bern ( $2^{\text {nd }}$ edition).

GeOrge, A.L. [1979], „The Causal Nexus Between Cognitive Beliefs and Decision-Making Behavior: The ,Operational Code" Belief System“, in: L.S.FALKOWSKI (ED.): Psychological Models in International Politics, Westview: Boulder.

GERKEN, L. (ED.) [1995], Competition Among Institutions, Macmillan Press: Houndmills.

GRIMM, D. (ED.) [1994], Staatsaufgaben, Nomos: Baden-Baden.

HELDRICH, A. and SCHMIDTCHEN, G. [1982], Gerechtigkeit als Beruf: Repräsentativumfrage unter jungen Juristen, Beck: München.

HÉRITIER, A. [1993], „Policy-Analyse: Elemente der Kritik und Perspektiven der Neuorientierung“, pp. 9-38 in: ID. (ED.), Policy-Analyse: Kritik und Neuorientierung = Politische Vierteljahresschrift Sonderheft 24.

HÉRITIER, A. [1999], Policy-Making and Diversity in Europe: Escaping Deadlock, Cambrigde University Press: Cambridge.

HÉRITIER, A., KNILL, C. and Mingers, S. [1996], Ringing the Changes in Europe: Regulatory Competition and Redefinition of the State: Britain, France, Germany, De Gruyter: Berlin.

HICKS, J. [1935], „Annual Survey of Economic Theory. The Theory of Monopoly“, Econometrica 3, 1-20.

HiRSCHMAN, A.O. [1970], Exit, Voice and Loyalty, Harvard University Press: Cambridge/Mass.

HÖFFE, O. [1999], , Wieviel Politik ist dem Verfassungsgericht erlaubt ?,“ Der Staat, 38, 171193.

ImMergut, E. [1992], Health Politics: Interests and Institutions in Western Europe, Cambridge University Press: Cambridge.

ISENSEE, J. [1996], „Bundesverfassungsgericht - quo vadis ?,“ Juristenzeitung, 51, 10851093. 
KERSTING, W. [1994], Die Politische Philosophie des Gesellschaftsvertrags, Wissenschaftliche Buchgesellschaft: Darmstadt.

Kersting, W. [1997], „,Moralphilosophie, Dezisionismus und pragmatische Rationalität“, pp. 353-396 in: ID. Recht, Gerechtigkeit und demokratische Tugend: Abhandlungen zur praktischen Philosophie der Gegenwart, Suhrkamp: Frankfurt.

KOFMAN, F. and LAWARRÉE, J. [1996], „A prisoner's dilemma model of collusion deterrence“, Journal of Public Economics ,59, 117-136.

LAFFONT, J.J. [1999], „Political Economy, information and incentives“, European Economic Review, 43, 649-669.

LANDES, W.M. and POSNER, R.A. [1975], „The independant judiciary from an interest group perspective“, Journal of Law and Economics 18, 875-901.

LERCHE, P. [1961], Übermaß und Verfassungsrecht. Zur Bindung des Gesetzgebers an die Grundsätze der Verhältnismäßigkeit und der Erforderlichkeit, Heymann: Köln.

Limbach, J. [1999], „Im Namen des Volkes“: Macht und Verantwortung der Richter, Deutsche Verlags-Anstalt: Stuttgart.

Luhmann, N. [1986], Ökologische Kommunikation: Kann die moderne Gesellschaft sich auf ökologische Gefährdungen einstellen ?, Westdeutscher Verlag: Opladen.

MüLLER, F. [1989], Juristische Methodik, Duncker \& Humblot: Berlin ( $3^{\text {rd }}$ edition).

POPPER, K.R. [1957], The Poverty of Historicism, Routledge: London.

RAISER, T. [1995], Das lebende Recht. Rechtssoziologie in Deutschland, Nomos: BadenBaden ( $2^{\text {nd }}$ edition).

RASEHORN, T. [1989], Der Richter zwischen Tradition und Lebenswelt: Alternative Justizsoziologie, Nomos: Baden-Baden.

RAU, C. [1996], Selbst entwickelte Grenzen in der Rechtsprechung des United States Supreme Court und dee Bundesverfassungsgerichts, Duncker \& Humblot: Berlin.

RichteR, R. and Furubotn, E.G. [1999], Neue Institutionenökonomik: Eine Einführung und kritische Würdigung, Mohr: Tübingen ( $2^{\text {nd }}$ edition).

SCHARPF, F.W. [1997], Games Real Actors Play: Actor-Centered Institutionalism in Policy Research, Westview: Boulder.

SCHARPF, F.W. [1999], Regieren in Europa: Effektiv und demokratisch ?, Campus: Frankfurt.

SCHLAICH, K. [1997], Das Bundesverfassungsgericht: Stellung, Verfahren, Entscheidungen, Beck: München ( $4^{\text {th }}$ edition).

SCHUlTE, M. [1996], „Zur Lage und Entwicklung der Verfassungsgerichtsbarkeit“, Deutsches Verwaltungsblatt, 111, 1009-1020.

SCHUlZE-FIELITZ, H. [1997], „Das Bundesverfassungsgericht in der Krise des Zeitgeists: Zur Metadogmatik der Verfassungsinterpretation," Archiv des öffentlichen Rechts, 122, 1-31.

SCHWEIZER, U. [1999], Vertragstheorie, Mohr: Tübingen. 
SimON, H. [1994], „Verfassungsgerichtsbarkeit“, pp. 1637-1680, in: BENDA, E., MAIHOFER, W. and Vogel, H.-J., Handbuch des Verfassungsrechts der Bundesrepublik Deutschland II, De Gruyter: Berlin ( $2^{\text {nd }}$ edition).

SPIECKER, I. [2000], „Staatliche Entscheidungen unter Unsicherheit: Juristische und ökonomische Vorgaben," forthcoming.

Thompson, M., Ellis, R. and Wildavsky, A. [1990], Cultural Theory, Westview Press: Boulder.

TIROLE, J. [1986], „Hierarchies and Bureaucracies: On the Role of Collusion in Organizations“, Journal of Law, Economics and Organization 2, 181-214.

TIROLE, J. [1994], „,The Internal Organization of Government“, Oxford Economic Papers, 46, $1-29$.

TRIBE, L.H. [1988], American Constitutional Law, Foundation Press: New York (2 ${ }^{\text {nd }}$ edition).

UMBACH, D. [1984], „Das Wesentliche an der Wesentlichkeitstheorie“, pp. 111-131, Festschrift Hans Joachim Faller, Beck: München.

VON WANGENHEIM, G. [1995], Die Evolution von Recht. Ursachen und Wirkungen häufigkeitsabhängigen Verhaltens in der Rechtsfortbildung, Mohr (Siebeck): Tübingen.

WEGNER, G. [1996], Wirtschaftspolitik zwischen Selbst- und Fremdsteuerung: ein neuer Ansatz, Nomos: Baden-Baden.

YEE, A.S. [1996], „The Causal Effect of Ideas on Politics“, International Organization, 50, 69-108.

Zimbardo, P. [1969], The Cognitive Control of Motivation: The Consequences of Choice and Dissonance, Scott: Glenview, Ill. 